\title{
Utilização do lúdico no atendimento de crianças hospitalizadas em unidades pediátricas: o papel do terapeuta ocupacional
}

\author{
Graziele Carolina de Almeida Marcolin, Anézia Moreira Faria Madeira, Mateus Marcolin, Alan
} Rodrigues de Souza, Amanda Conrado Silva Barbosa, Thaís Amanda de Assis

\begin{abstract}
Resumo
Trata-se de um tema polêmico, que atualmente vem conquistando espaço no processo de humanização do atendimento à criança hospitalizada. $\mathrm{O}$ brincar no contexto hospitalar tem sido visto como uma técnica voltada ao tratamento da criança que padece de internação de longa permanência. O Terapeuta Ocupacional, por sua vez, apresenta-se neste contexto como o profissional mais capacitado e apto a desenvolver atividades de estimulação para a criança, utilizando-se do lúdico como subsídio para tratamento da mesma no ambiente hospitalar. Estudos recentes têm investigado este tema empiricamente, disponibilizando publicações científicas importantes para fomentar o processo da prática baseada em evidências. Logo, o objetivo deste estudo é analisar a influência do lúdico na estimulação de crianças hospitalizadas por meio da atuação do Terapeuta Ocupacional. Dessa forma, a metodologia utilizada foi o relato de experiência, o qual ocorreu por meio da observação da atuação do Terapeuta Ocupacional em Hospital específico no Município de Conselheiro Lafaiete - MG. Os resultados evidenciados pelos estudos identificaram que o brincar no ambiente hospitalar efetivado pelo Terapeuta Ocupacional pode melhorar a exposição de sentimentos da criança, assim como seu humor, vínculo com as demais crianças e familiares presentes no contexto hospitalar; melhorando ainda seu desenvolvimento mesmo em estado de internação. A inserção de atividades lúdicas com utilização de brincadeiras/do brinquedo/do brincar no contexto hospitalar pode proporcionar às crianças internadas benefícios diversos, como expressão de sentimentos e de vivências, aceitação do tratamento e de intervenções, e melhora no estado emocional. A Terapia Ocupacional e a vinculação do brincar no contexto hospitalar revestem o ambiente de alegria, descontração e tranquilidade, diminuindo as angústias/frustrações vividas pelas crianças. Além disso, a participação do Terapeuta Ocupacional na estimulação da criança hospitalizada por meio do brincar proporciona um ambiente mais humanizado e agradável, o que de certa forma vincula a criança ao meio social em que ela vive. Por outro lado, analisando-se as dificuldades existentes vê-se que, nem toda unidade pediátrica disponibiliza o profissional, com o fim de estimular a recuperação de crianças por meio do brincar. Muitas vezes esta atividade é realizada por outros profissionais, como Psicólogos, Enfermeiros, Fisioterapeutas, dentre outros. Neste sentido, este trabalho aponta para a necessidade da inserção do Terapeuta Ocupacional no contexto pediátrico, para ajudar a minimizar os efeitos da hospitalização através da ludoterapia. Vale ressaltar que, a incorporação dos familiares neste processo é de fundamental importância, uma vez que a criança poderá se sentir mais tranquila e protegida por ocasião das atividades, e os responsáveis esquecerem por algum tempo o sofrimento advindo da internação do filho. Assim, a síntese disponibilizada pelo presente estudo pode ajudar a nortear Terapeutas Ocupacionais nas estratégias de tratamento e de intervenção da criança hospitalizada através do brincar visando promover a participação, desenvolvimento e atividade da criança hospitalizada.
\end{abstract}

Descritores: Hospitalização; Brincar; Terapeuta Ocupacional. 